\title{
Unilateral Muscle Artifacts due to Non-compliance During Uptake Phase of I8F-FDG PET/CT in an Oncologic Patient
}

\author{
Bir Onkoloji Hastasında I8F-FDG PET/BT Tutulum Fazı Sırasında Uyumsuzluğa Bağıı Unilateral \\ Kas Artefaktları
}

William Makis, (1) Emmanuel W. Hudson

Cross Cancer Institute, Department of Diagnostic Imaging, Edmonton, Canada

\begin{abstract}
A 49-year-old male patient with a prior history of poor compliance with medical appointments was referred for an 18F-fluoro2-deoxy-D-glucose (18F-FDG) positron emission tomography/computed tomography (PET/CT) for the staging of a rectal squamous cell carcinoma. The PET/CT showed unilateral diffuse skeletal muscle 18F-FDG uptake as well as bilateral salivary gland uptake artifacts, suggestive of non-compliance with patient preparation instructions. The PET/CT nurse noted that during the 18F-FDG uptake phase, the patient appeared intoxicated, and she found two beer cans hidden in the waste disposal beside his chair just prior to imaging. The patient only admitted to eating a cookie approximately 30 minutes after the injection of 18 F-FDG PET/CT and denied consuming alcohol during the uptake phase. We present the imaging findings of non-compliance with patient instructions during the uptake phase of $18 \mathrm{~F}-\mathrm{FDG}$.
\end{abstract}

Keywords: Non-compliance, artifact, pitfall, muscle, musculoskeletal, 18F-FDG, PET

\section{Öz}

Kırk dokuz yaşında doktor randevularına uyumsuz olduğu bilinen bir erkek hasta rektal skuamöz hücreli karsinom evrelemesi amacıyla 18F-fluoro-2-deoksi-D-glukoz (18F-FDG) pozitron emisyon tomografisi/bilgisayarlı tomografi (PET/BT) için yönlendirilmişti. PET/BT'de unilateral diffüz iskelet kasında 18F-FDG tutulumu, bilateral tükrük bezi artefaktları görüldü, bulguları hastanın hazırlık talimatlarına uyumsuzluğu olarak değerlendirildi. PET/BT hemşiresi 18F-FDG tutulumu sırasında hastanın intoksike görünümde olduğunu farketti ve görüntülemeden önce hastanın iskemlesinin yanındaki çöp kutusunda iki bira şişesi buldu. Hasta 18F-FDG PET/BT enjeksiyonundan 30 dakika sonra bir kurabiye yediğini ancak alkol almadığını belirtti. Burada hazırlık talimatlarına uyumsuz bir hastada 18F-FDG tutulum fazındaki görüntüleme bulgularını sunuyoruz.

Anahtar kelimeler: Uyumsuzluk, artefakt, tuzak, kas, kas-iskelet, 18F-FDG, PET

Address for Correspondence: William Makis MD, Cross Cancer Institute, Department of Diagnostic Imaging, Edmonton, Canada Phone: +90 7804328760 E-mail: makisw79@yahoo.com ORCID ID: orcid.org/0000-0003-0241-3426

Received: 30.12.2016 Accepted: 15.10.2017

${ }^{\circ}$ Copyright 2018 by Turkish Society of Nuclear Medicine

Molecular Imaging and Radionuclide Therapy published by Galenos Yayınevi. 

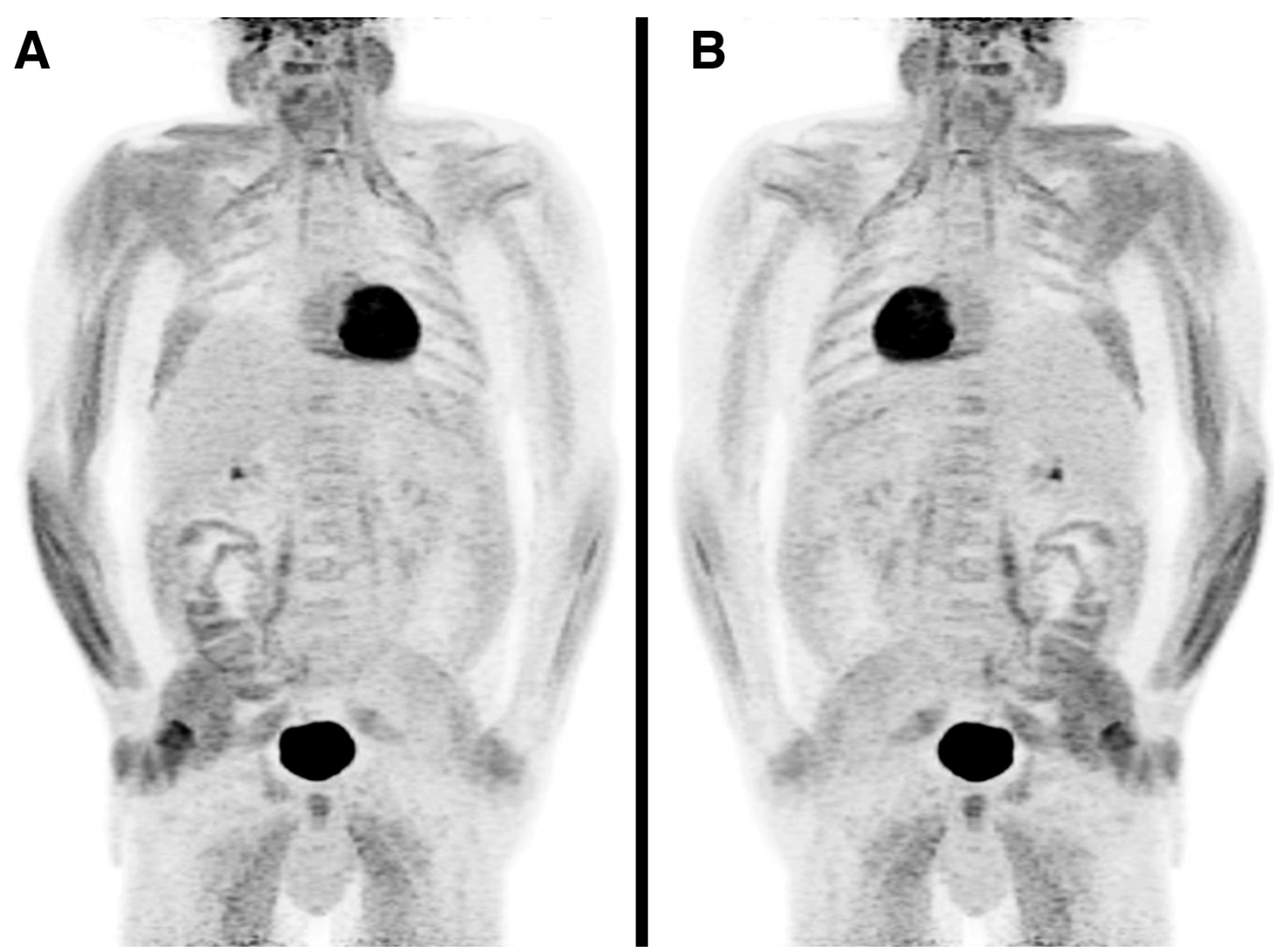

Figure 1. A 49-year-old male patient had 18F-fluoro-2-deoxy-D-glucose (18F-FDG) positron emission tomography/computed tomography (PET/CT) (Biograph-mCT, Siemens, Germany) to stage a rectal squamous cell carcinoma. He was injected with $352 \mathrm{MBq}$ of $18 \mathrm{~F}-\mathrm{FDG}$ and his blood glucose was $6.8 \mathrm{mmol} / \mathrm{L}$ just prior to injection. During the 60-minute uptake phase prior to imaging, the nurse observed the patient: he was sitting and leaning on one side, appeared intoxicated and his breath smelled of alcohol. He was constantly moving in his seat. Two beer cans were found in the waste disposal next to his chair just prior to imaging. On questioning, he denied drinking alcohol and only admitted to eating a cookie at approximately 30 minutes after 18F-FDG injection. PET/CT maximum intensity projection images with (A) anterior and (B) posterior views revealed diffuse intense unilateral muscle 18F-FDG uptake artifacts involving the right shoulder, arm, hand, right chest wall and right gluteus muscles. 


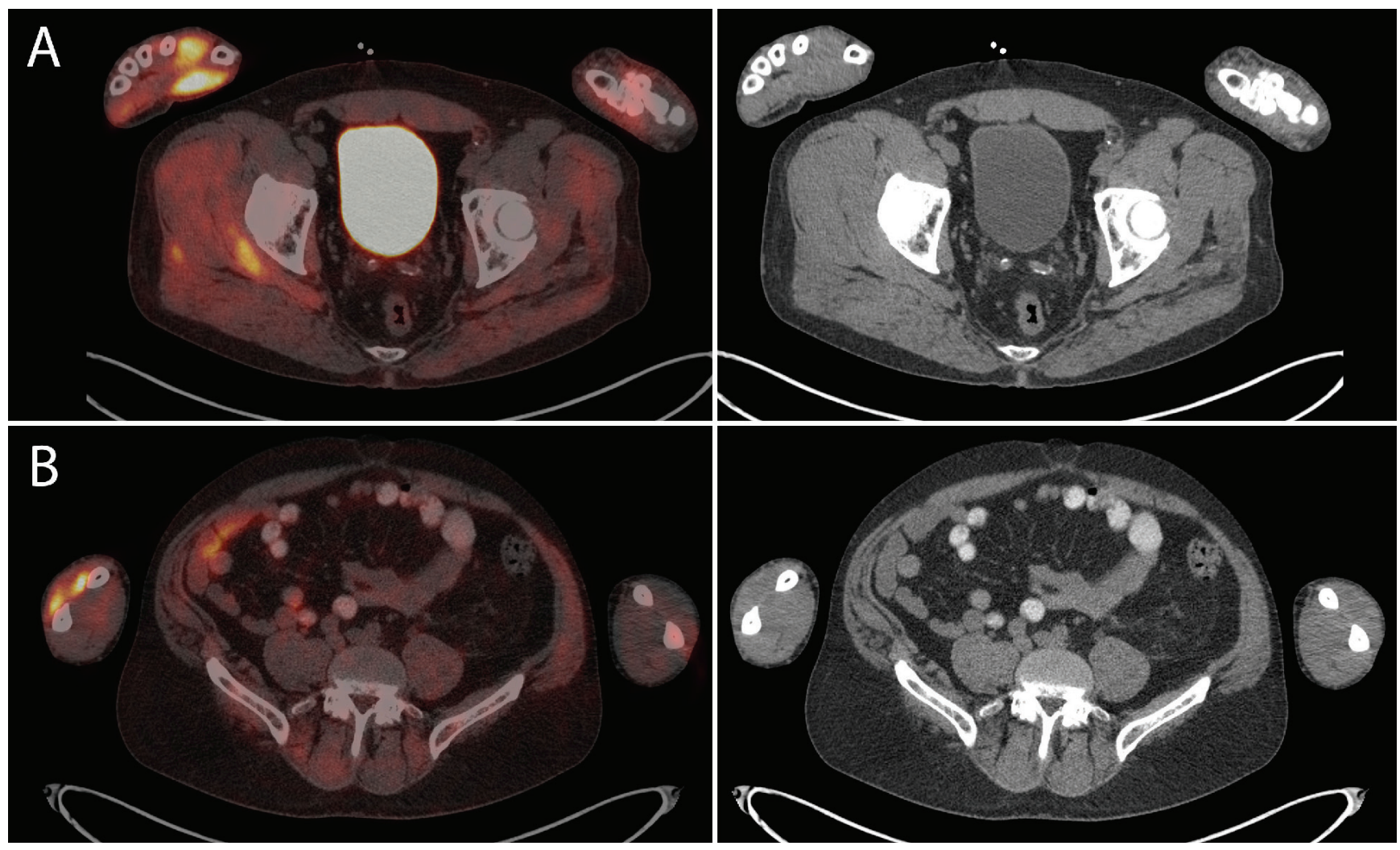

Figure 2. (A) Intense 18 F-FDG uptake in the right thenar eminence with maximum standard uptake value (SUV $\max ) 8.8$ was the most intensely $18 \mathrm{~F}$-FDG avid abnormality in the entire PET/CT study, and was most likely the result of the patient holding beer cans and drinking beer. (B) Right dorsal extensor forearm muscles also showed intense 18 F-FDG uptake with SUV $\max 6.7$.

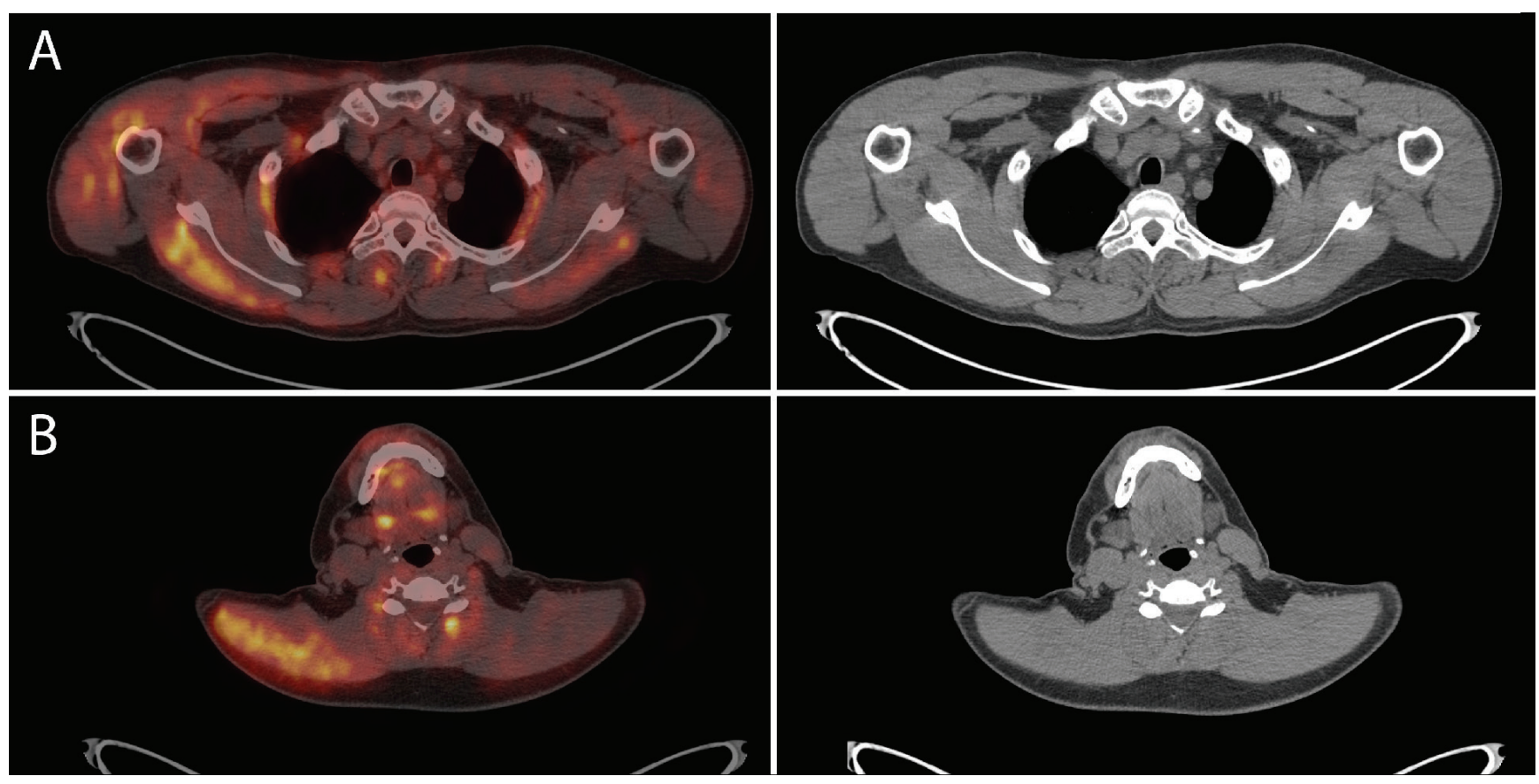

Figure 3. Right biceps muscles showed increased 18F-FDG uptake with $S U V_{\max } 5.0$, (A) right shoulder muscles had SUV $\max 4.0$, (B) right trapezius muscle had SUV $V_{\max } 4.1$ and right serratus anterior muscle had SUV $\mathrm{max}_{\max } 3.8$. 

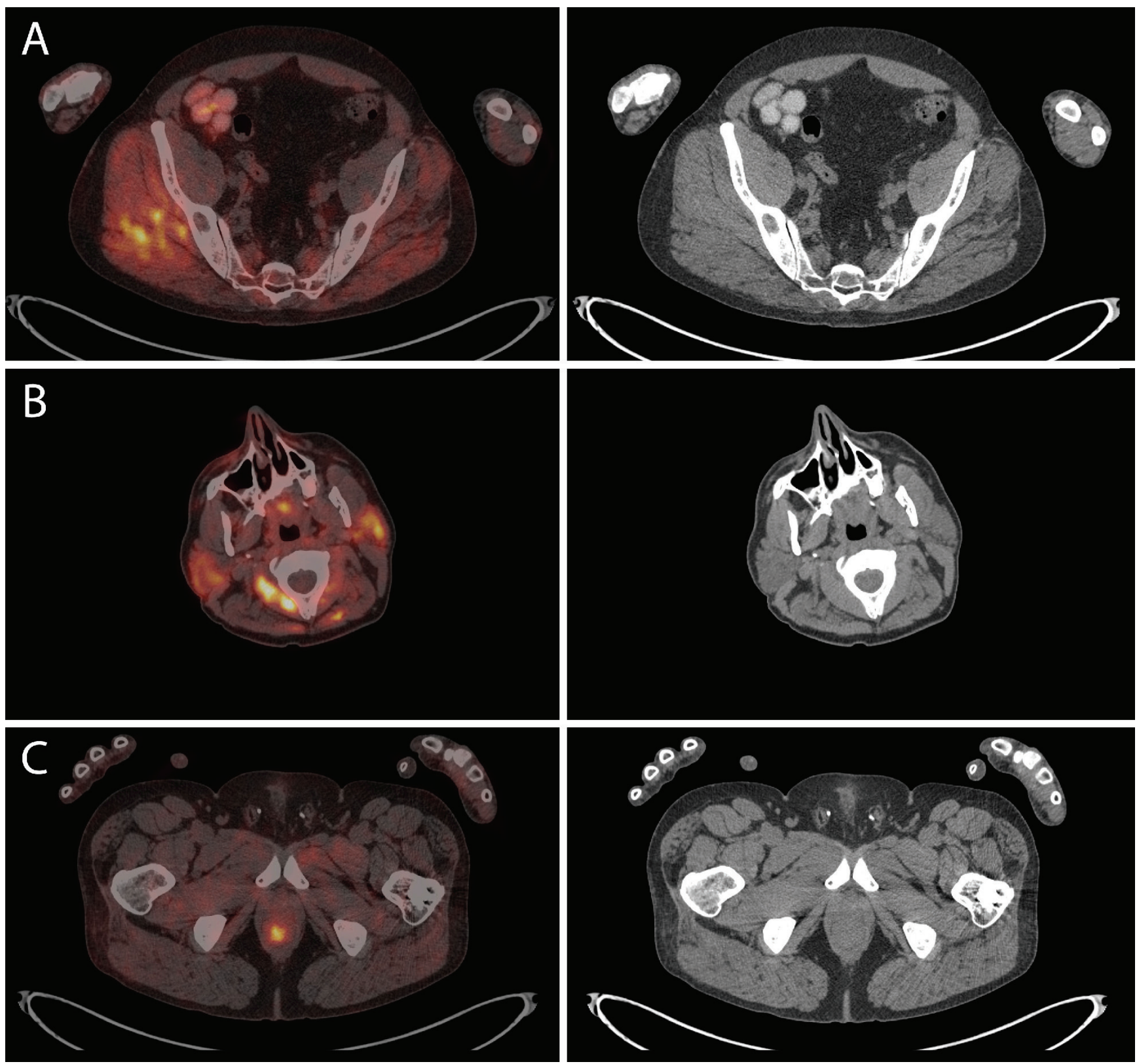

Figure 4. (A) Right gluteal muscles showed increased ${ }^{18 F-F D G}$ uptake with $S U V_{\max } 5.3$, and (B) both parotid glands showed increased $18 \mathrm{~F}-\mathrm{FDG}$ uptake with SUV $\max 4.7$ in the right and SUV $V_{\max } 4.8$ in the left, most likely due to alcohol/food consumption. (C) The rectal primary lesion had intense 18F-FDG uptake with SUV $\max 5.2$ and there was no evidence of distant metastases. The 18F-FDG physiologic uptake artifacts from physical activity and movements of the right hand, arm, shoulder and gluteus maximus (as well as drinking and eating), with normal corresponding CT findings, did not interfere with cancer staging. It is important that a patient is relaxed at time of $18 \mathrm{~F}-\mathrm{FDG}$ injection and has avoided vigorous exercise in the hours leading up to the PET/CT. Most authors recommend avoiding physical exercise 24 hours before 18F-FDG administration $(1,2,3,4)$, although vigorous exercise up to 4 days before imaging has been reported to cause muscle 18F-FDG uptake artifacts (5). Diffusely increased 18F-FDG uptake in muscles, as a PET/ CT artifact, has been described in the following situations: insulin administration (6), voluntary physical activity such as chewing gum, exercise or sexual activity $(4,5,7)$, involuntary physical activity such as labored breathing or muscle spasms (8), post surgical changes $(9,10)$, post radiation inflammation (11), dermatomyositis (12), infection $(10,13,14)$, or post injection (15). Unilateral intense muscle 18F-FDG uptake is rare and has been described in a few cases such as hemiparesis from stroke (16), in patients with multiple sclerosis (17), due to tracer injections (15) or more commonly in certain head and neck muscles (18). Non-compliance with patient instructions during the uptake phase of 18F-FDG can cause significant artifacts and recent examples in the literature include smartphone use (19), reading a small book and even tapping the foot (20). 


\section{Ethics}

Informed Consent: All subjects in the study gave written informed consent or the institutional review board waived the need to obtain informed consent.

Peer-review: External and internal peer-reviewed.

\section{Authorship Contributions}

Surgical and Medical Practices: W.M., E.W.H., Concept: W.M., Design: W.M., Data Collection or Processing: W.M., E.W.H., Analysis or Interpretation: W.M., E.W.H., Literature Search: W.M., E.W.H., Writing: W.M.

Conflict of Interest: No conflict of interest was declared by the authors.

Financial Disclosure: The authors declared that this study received no financial support.

\section{References}

1. Cook G, Wegner EA, Fogelman I. Pitfalls and artifacts in 18FDG PET and PET/CT oncologic imaging. Semin Nucl Med 2004;34:122-133.

2. Rosenbaum SJ, Lind T, Antoch G, Bockisch A. False-positive FDG PET uptake - the role of PET/CT. Eur Radiol 2006;16:1054-1065.

3. Yasuda S, Ide M, Takagi S, Shohtsu A. Elevated F-18 FDG uptake in skeletal muscle. Clin Nucl Med 1998;23:111-112.

4. Choi BW, Kim SH, Kim HW, Won KS, Zeon SK. Hypermetabolism of skeletal muscles following sexual activity: a normal variation. Nucl Med Mol Imaging 2010;44:228-229.

5. Bai $X$, Wang $X$, Zhuang $H$. Long-lasting FDG uptake in the muscles after strenuous exercise. Clin Nucl Med 2015;40:975-976.

6. Blodgett TM, Mehta AS, Mehta AS, Laymon CM, Carney J, Townsend DW. PET/CT artifacts. Clin Imaging 2011;35:49-63.

7. Kawabe J, Higashiyama S, Okamura T, Torii K, Koyama K, Kawamura $E$, Ishizu $H$, Inoue $Y$, Shiomi S. FDG uptake by tongue and muscles of mastication reflecting increased metabolic activity of muscles after chewing gum. Clin Nucl Med 2003;23:220-221.

8. Lin Fl, Foster CC, Hagge RJ, Shelton DK. Extensive FDG uptake in accessory muscles of respiration in a patient with shortness of breath. Clin Nucl Med 2009;34:428-430.

9. Costelloe CM, Murphy WA, Chasen BA. Musculoskeletal pitfalls in 18F-FDG PET/CT: pictorial review. AJR Am J Roentgenol 2009;193(Suppl 3):WS1-WS13.

10. Love C, Tomas MB, Tronco GG, Palestro CJ. FDG PET of infection and inflammation. Radiographics 2005;25:1357-1368.

11. Tomita H, Kita T, Hayashi K, Kosuda S. Radiation-induced myositis mimicking chest wall tumor invasion in two patients with lung cancer: a PET/CT study. Clin Nucl Med 2012;37:168-169.

12. Mahmood S, de Llano SRM. 18F-FDG PET detection of unknown primary malignancy in dermatomyositis. Clin Nucl Med 2012;37:e204-e205.

13. Strobel K, Stumpe KD. PET/CT in musculoskeletal infection. Semin Musculoskelet Radiol 2007;11:353-364.

14. Palestro CJ. FDG-PET in musculoskeletal infections. Semin Nucl Med 2013;43:367-376.

15. Nakatani K, Nakamoto $Y$, Togashi K. Unilateral physiological FDG uptake in teres minor muscle seems well associated with IV tracer injection procedures. Clin Nucl Med 2015;40:62-64.

16. Gupta P, Kota G, Alavi A, Mintz A. Unilateral diffusely increased muscle uptake of F-18 FDG in a patient with hemiparesis due to stroke. Clin Nucl Med 2011;36:1140-1141.

17. Rudroff $T$, Kindred JH, Koo PJ, Karki R, Hebert JR. Asymmetric glucose uptake in leg muscles of patients with multiple sclerosis during walking detected by [18F]-FDG PET/CT. NeuroRehabilitation 2014;35:813-823.

18. Lin EC. Focal asymmetric longus colli uptake on FDG PET/CT. Clin Nucl Med 2007:32:67-69.

19. Schwartz P Jr, Pinaquy JB. Unilateral forearm muscle 18F-FDG uptake after using a smartphone. Clin Nucl Med 2015;40:e532-e533.

20. Jackson RS, Schlarman TC, Hubble WL, Osman MM. Prevalence and patterns of physiologic muscle uptake detected with whole-body 18F-FDG PET. J Nucl Med Technol 2006;34:29-33. 